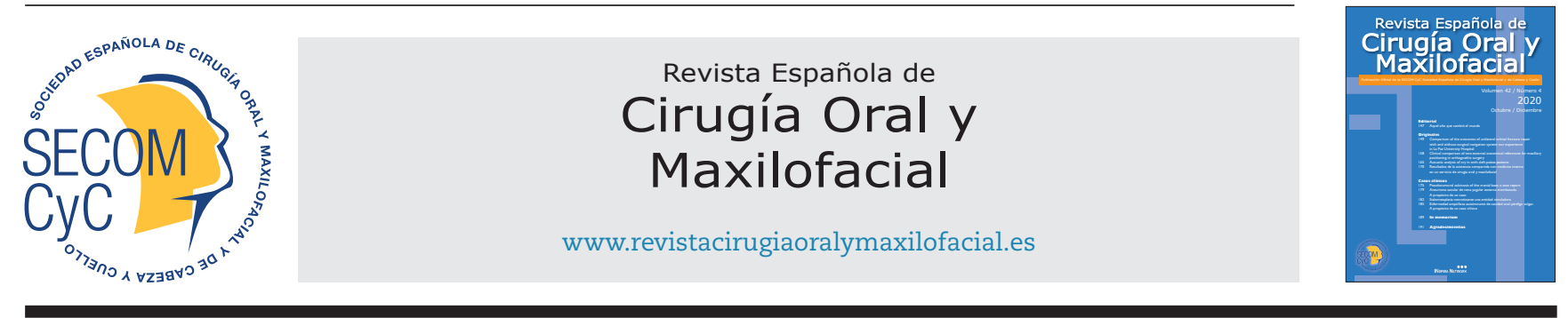

\title{
Original
}

\section{Clinical comparison of two external anatomical references for maxillary positioning in orthognathic surgery}

\author{
Mauricio Barreda Hale ${ }^{1}$, Jorge Lolas Millard ${ }^{1,2}$, Emilio Moreno Apablaza ${ }^{1,2}$, \\ Daniel Pino Díaz ${ }^{1,2}$, Camila Arrué Torres ${ }^{3}$ y Javiera Beytía Erazo ${ }^{3}$
}

${ }^{1}$ Department of Oral and Maxillofacial Surgery, Hospital del Salvador, Santiago, Chile. ${ }^{2}$ Department of Maxillofacial Surgery and Traumatology. Universidad de los Andes, Santiago, Chile. ${ }^{3}$ Private practice Dentistry, Santiago, Chile

\section{INFORMACIÓN DEL ARTÍCULO}

Historia del artículo:

Recibido: 12 de diciembre de 2019

Aceptado: 10 de junio de 2020

\section{Keywords:}

Facial asymmetry, Le Fort osteotomy, maxillary osteotomy, medial canthus, nasal pin, orthognathic surgery.

\begin{abstract}
A B S T R A C T
Introduction: The use of external reference points (ERP) like the nasal pin (NP) and eye's medial canthus (EMC) provides a stable and reproductible landmarks for maxillary repositioning. ERP are widely used, for its practicality to achieve the desired aesthetic result in orthognathic surgery (OS).

Objectives: The purpose of this study is to compare the ERPs: NP and EMC, to define which is the most accurate, and also define its limitations, in the intraoperative phase for vertical repositioning of the maxilla.

Patients and methods: We performed a retrospective study on 26 patients who underwent OS from December 2015 to August 2018. Previous to the Le Fort I osteotomy, the vertical measurements were made. The most accurate ERP was considered to be the one that obtained the least average difference between the vertical measurement of the pre-surgical planning and that obtained in the intraoperative period.

Results: The planned vertical movement was an average of $-1.73 \mathrm{~mm} \pm 1.97 \mathrm{SD}$, with the largest maxillary impaction movement of $-6 \mathrm{~mm}$ and the largest maxillary descent of $2 \mathrm{~mm}$. The difference between planned vertical movement and obtained measurements of vertical change for NP had an average $0.05 \mathrm{~mm} \pm 0.51 \mathrm{SD}(95 \% \mathrm{CI},-0.15-0.26)$, and the difference between planned vertical movement and obtained measurements for EMC had an average $1.23 \mathrm{~mm} \pm 1.29 \mathrm{SD}(95 \% \mathrm{CI}, 0.71-1.75)$, with a statistically significant difference $(\mathrm{p}=0.0001)$ between them of $-1.18 \mathrm{~mm} \pm 1.23$ (95\% CI, -1.67 - -0.68).

Conclusions: The use of the NP as an ERP provides greater precision and predictability of movement in the vertical repositioning of the maxillomandibular-complex, compared to the use of EMC. Both techniques can be used as a complement, being aware of the effect of triangulation.
\end{abstract}

\footnotetext{
*Autor para correspondencia:

Correo electrónico: mbarredah@gmail.com (Mauricio Barreda-Hale).

DOI: $10.20986 /$ recom.2020.1108/2019
}

1130-0558/@ 2020 SECOM. Publicado por Inspira Network. Este es un artículo Open Access bajo la licencia CC BY-NC-ND (http:// creativecommons.org/licenses/by-nc-nd/4.0/). 


\title{
Comparación clínica de las referencias anatómicas externas para posicionamiento maxilar en cirugía ortognática
}

\author{
R E S U M E N
}

Palabras clave:

Asimetría facial, osteotomía de Le Fort, osteotomía maxilar, canthus medial, pin nasal, cirugía ortognática.

\begin{abstract}
Introducción: El uso de puntos de referencia externos (ERP) como el pin nasal (NP) y el canto medial del ojo (EMC) proporciona puntos de referencia estables y reproducibles para el reposicionamiento maxilar. Los ERP son ampliamente utilizados por su practicidad para lograr el resultado estético deseado en cirugía ortognática (OS).

Objetivos: El propósito de este estudio es comparar los ERP (NP y EMC), para definir cuál es el más preciso, y también definir sus limitaciones, en la fase intraoperatoria para el reposicionamiento vertical del maxilar.

Pacientes y métodos: Realizamos un estudio retrospectivo en 26 pacientes que se sometieron a OS desde diciembre de 2015 hasta agosto de 2018. Antes de la osteotomía de Le Fort I, se realizaron las mediciones verticales. Se consideró el ERP más preciso el que obtuvo la menor diferencia promedio entre la medición vertical de la planificación prequirúrgica y la obtenida en el periodo intraoperatorio.

Resultados: El movimiento vertical planeado fue un promedio de $-1,73 \mathrm{~mm} \pm 1,97 \mathrm{SD}$, con el mayor movimiento de impactación maxilar de $-6 \mathrm{~mm}$ y el mayor descenso maxilar de $2 \mathrm{~mm}$. La diferencia entre el movimiento vertical planificado y las medidas obtenidas de cambio vertical para NP tuvo un promedio de 0,05 mm \pm 0,51 DE (IC $95 \%,-0,15-0,26$ ), y la diferencia entre el movimiento vertical planificado y las medidas obtenidas para EMC tuvo un promedio de 1,23 mm $\pm 1,29 \mathrm{DE}$ (IC $95 \%, 0,71-1,75$ ), con una diferencia estadísticamente significativa $(p=0,0001$ ) entre ellos de $-1,18 \mathrm{~mm} \pm 1,23$ (IC $95 \%,-1,67--0,68)$.

Conclusiones: El uso del NP como ERP proporciona mayor precisión y previsibilidad del movimiento en el reposicionamiento vertical del complejo maxilomandibular, en comparación con el uso de EMC. Ambas técnicas se pueden utilizar como complemento, teniendo en cuenta el efecto de la triangulación.
\end{abstract}

\section{INTRODUCTION}

In orthognathic surgery (OS), the three-dimensional positioning of the intraoperative maxilla involves vertical movement, which is critical to achieving optimal aesthetic and functional results. The vertical position of the maxilla is frequently adjusted in the intraoperative phase, sometimes varying the planned bone movements, to improve the aesthetic results of the lip-dental relationship.

Conventional planning in gypsum models allows arbitrary vertical and horizontal reference according to the spatial positioning of the articulated models, extrapolating bone points as landmarks, for example, the anterior nasal spine. Otherwise, three-dimensional planning allows measurements to be made from the patient's scanner in both hard and soft tissues, however, intraoperatively the landmarks used generally correspond to points defined at that time, either the nasion point as a fixed bone reference using a nasal pin (NP) or the medial canthus of the eye (EMC) as landmarks in soft tissues.

External reference points (ERP) have been used as an accuracy method to determinate placement of the maxilla on $\mathrm{OS}^{1}$. The use of this points provides a stable and reproductible landmarks for vertical positioning using a Kirschner wire (K-Wire) or a mini-screw as NP and also the EMC, generally these two being the most used. The most used sites to insert the pin are the nasion and the glabella, but otherwise, the use of the medial canthus has been proposed as an atraumatic alter- native and without the risk of complications both intra and postoperative, such as perforation of the anterior wall of the frontal sinus, perforation of the posterior wall of the frontal sinus, frontal sinusitis, hemorrhage, hematoma, damage to neurovascular structures ${ }^{2,3}$

The purpose of this study is to compare the ERPs, NP and EMC, to define which is the most accurate and reproducible in the intraoperative phase for vertical repositioning of the maxilla.

\section{PATIENTS AND METHODS}

In this retrospective study, 26 patients undergoing OS for the treatment of dentofacial dysmorphosis were analyzed during the period between december 2015 and august 2018 at the Hospital del Salvador, Santiago, Chile. All patients signed an informed consent for the use of their clinical records.

The selection criteria were patients with preoperative orthodontics, dental models with surgical feasibility, continuous dental arch and indication of a Le Fort I osteotomy. Patients with an indication for a maxillary osteotomy other than Fort I, segmental maxillary surgery, cleft patients, syndromic patients, dental agenesis and/or hypodontia were excluded. Those who previously underwent surgery were also excluded, like facial surgeries of the middle and upper third or who had nasal fractures, frontal sinus fractures. The surgeries performed were Le Fort I osteotomies in monomaxillary surgeries and associated with bilateral mandibular sagittal split osteotomies (BSSO) in 
bimaxillary surgeries, with or without genioplasty and the surgical sequence for all patients was maxillary first (Table I). All procedures were performed by the same first surgeon (M.B) and the same surgical team. This study was approved by the Ethics Committee of the Hospital of El Salvador.

Before the osteotomy, with a Vernier calliper, vertical linear measurements were performed that included the distances between the following reference points: For NP, a $40 \mathrm{~mm}$ $\mathrm{K}$-Wire was inserted into the glabellar region, 15 millimeters above the radiographic location of the nasion and 10 millimeters deep. The measurement was made from the NP to the portion of the orthodontic arch located between the maxillary central incisors (Figure 1). For the reference of the EMC, the measurement was made from the left medial canthus to the portion of the orthodontic arch located between the lateral incisor and the superior canine (Figure 2).

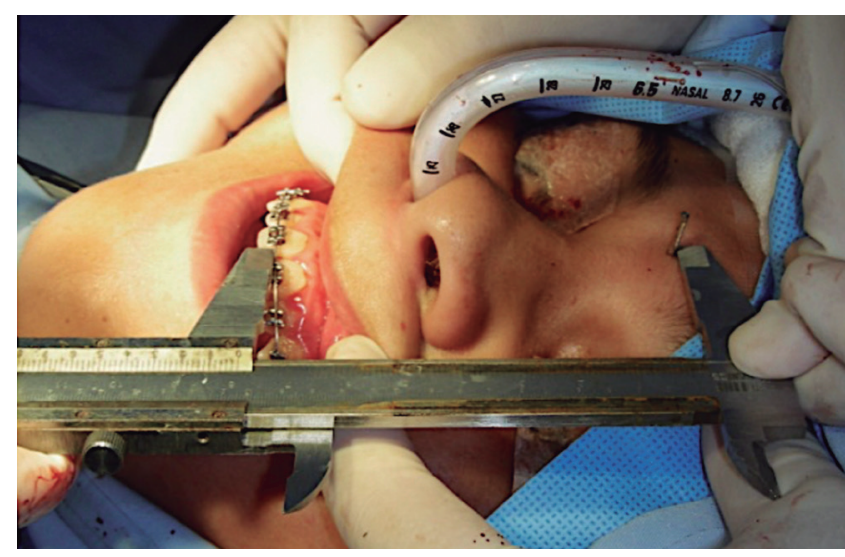

Figure 1. Intraoperative measurement using the nasal pin (K-Wire) as an external reference point.

Table I. General surgical information of the patients.

\begin{tabular}{|c|c|c|c|}
\hline Patient & PVC (mm) & Osteotomy type & $\begin{array}{l}\text { Maxillary sagittal } \\
\text { movement (mm) }\end{array}$ \\
\hline 1 & -4 & Le Fort I & 4 \\
\hline 2 & 0 & Le Fort I + BSSO & 4 \\
\hline 3 & -2 & Le Fort I + BSSO + Genioplasty & 5 \\
\hline 4 & -6 & Le Fort I + BSSO + Genioplasty & 6 \\
\hline 5 & 0 & Le Fort I & 3 \\
\hline 6 & -3 & Le Fort I + BSSO + Genioplasty & 2 \\
\hline 7 & 0 & Le Fort I + BSSO & 5 \\
\hline 8 & -3 & Le Fort I + BSSO & 6 \\
\hline 9 & -3 & Le Fort I + Genioplasty & 2 \\
\hline 10 & -3 & Le Fort I + BSSO + Genioplasty & 7 \\
\hline 11 & 0 & Le Fort I + BSSO + Genioplasty & 4 \\
\hline 12 & 0 & Le Fort I + BSSO + Genioplasty & 4 \\
\hline 13 & 0 & Le Fort I + Genioplasty & 5 \\
\hline 14 & 2 & Le Fort I + BSSO + Genioplasty & 4 \\
\hline 15 & -2 & Le Fort I + BSSO & 3 \\
\hline 16 & 0 & Le Fort I + Genioplasty & 5 \\
\hline 17 & -3 & Le Fort I + Genioplasty & 4 \\
\hline 18 & -2 & Le Fort I + BSSO & 6 \\
\hline 19 & -2 & Le Fort I + BSSO + Genioplasty & 5 \\
\hline 20 & -3 & Le Fort I + BSSO + Genioplasty & 7 \\
\hline 21 & -2 & Le Fort I + BSSO + Genioplasty & 6 \\
\hline 22 & -3 & Le Fort I + BSSO & 3 \\
\hline 23 & -4 & Le Fort I + BSSO + Genioplasty & 5 \\
\hline 24 & 0 & Le Fort I + BSSO + Genioplasty & 4 \\
\hline 25 & 2 & Le Fort I + BSSO + Genioplasty & 5 \\
\hline 26 & -4 & Le Fort I + Genioplasty & 5 \\
\hline $\mathrm{N}=26$ & $\begin{array}{c}\text { AVG } \\
-1.73 \pm 1.97\end{array}$ & $\begin{array}{c}\text { Maxillary only surgery: } 2 \text { (7.7\%) } \\
\text { Maxillary w/ genioplasty: } 5 \text { (19.3\%) } \\
\text { Bimaxillary w/o Genioplasty: } 6(23 \%) \\
\text { Bimaxillary w/ Genioplasty: } 13(50 \%)\end{array}$ & $\begin{array}{c}\text { AVG } \\
4.57 \pm 1.33\end{array}$ \\
\hline
\end{tabular}

PVC: Planned vertical change of the maxilla. Negative PVC: impaction. Positive PVC: maxillary descent. BSSO: bilateral mandibular sagittal split osteotomy. AVG: average \pm standard deviation. 


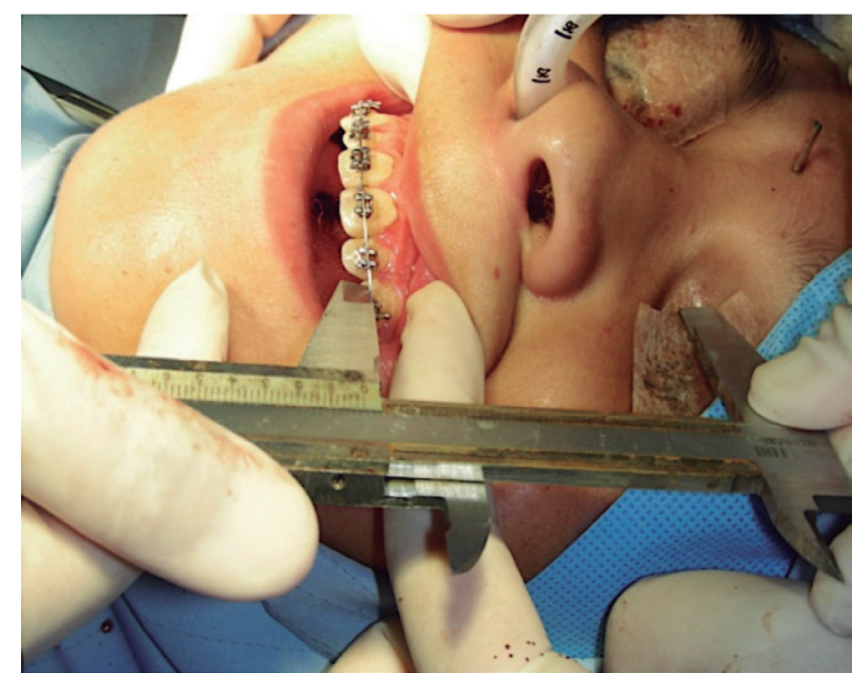

Figure 2. Intraoperative measurement using the medial canthus as an external reference point.

At the beginning of the procedure the starting point measurement was recorded and before fixing the maxilla in its new position new measurements were obtained to ensure that the planned vertical change of the maxilla (PVC) is met, avoiding a maxillary cant or an unplanned malposition with consequences on the aesthetic result. Both measurements were made during maxillary repositioning and were rechecked after internal rigid fixation, all measurements were made by the same operator (M.B).

The value of the difference between vertical measurements in preoperative planning and intraoperative measurements obtained from both ERPs (NP and EMC), was calculated and compared to evaluate the precision of both techniques in intraoperative vertical positioning of the maxilla. The most stable and predictable reference point was considered to be the one that obtained the least average difference between the vertical measurement of the pre-surgical planning and that obtained in the intraoperative period.

The data obtained showed a normal distribution verified with the Shapiro-Wilk test and were analyzed using a paired $\mathrm{t}$-test and the $\mathrm{T}$ and $\mathrm{p}$ values were obtained using the Stata 13 software (StataCorp. 2013, TX, USA). Statistical significance was established with $\mathrm{p}<0.05$.

\section{RESULTS}

The study sample was made up of 26 patients and a total of 156 measurements were analyzed. The average age was $22 \pm 5.97$ years, $57.6 \%$ were women $(n=15)$ and $42.4 \%$ were men $(\mathrm{n}=11)$.

The PVC was an average of $-1.73 \mathrm{~mm} \pm 1.97$ (95\% CI, -2.49 - -0.97), with the largest maxillary impaction movement of $-6 \mathrm{~mm}$ and the largest maxillary descent of $2 \mathrm{~mm}$. Negative values were considered as maxillary elevation or impaction and positive values as descent in the final vertical position of the maxilla (Table II). The difference between planned vertical movement and obtained measurements of vertical change for
NP had an average $0.05 \mathrm{~mm} \pm 0.51 \mathrm{SD}$ (95\% CI, $-0.15-0.26$ ), and the difference between planned vertical movement and obtained measurements for EMC had an average $1.23 \mathrm{~mm}$ \pm 1.29 SD (95 \% CI, 0.71 - 1.75), with a statistically significant difference $(\mathrm{p}=0.0001)$ between them of $-1.18 \mathrm{~mm} \pm 1.23$ (95\% CI, -1.67 - -0.68).

The percentage of the type of osteotomy performed in the patients was $7.7 \%$ only in Le Fort I monomaxillary surgery, maxillary surgery with genioplasty $19.3 \%$, bimaxillary surgery with or without genioplasty $23 \%$, and bimaxillary surgery with genioplasty $50 \%$. The average maxillary advance was $4.57 \mathrm{~mm}$ \pm 1.33 (95\% CI, 4.06 - 5.08) (Table III).

Table II. Intraoperative measurements using nasal pin reference and its comparison with the vertical position defined in the pre-surgical planning.

\begin{tabular}{|c|c|c|c|c|}
\hline Patient & $\begin{array}{l}\text { NP Pre } \\
(\mathrm{mm})\end{array}$ & $\begin{array}{l}\text { NP Post } \\
(\mathrm{mm})\end{array}$ & $\begin{array}{c}\text { NP Pre/ } \\
\text { post } \\
\text { difference } \\
(\mathrm{mm})\end{array}$ & $\begin{array}{c}\text { PVC/NP } \\
\text { post } \\
\text { difference }\end{array}$ \\
\hline 1 & 90 & 86 & -4 & 0 \\
\hline 2 & 86 & 86 & 0 & 0 \\
\hline 3 & 89.4 & 87.5 & -1.9 & 0.1 \\
\hline 4 & 94 & 88.5 & -5.5 & 0.5 \\
\hline 5 & 79 & 80 & 1 & 1 \\
\hline 6 & 85 & 82 & -3 & 0 \\
\hline 7 & 87 & 87.5 & 0.5 & 0.5 \\
\hline 8 & 76 & 73 & -3 & 0 \\
\hline 9 & 83 & 80.6 & -2.4 & 0.6 \\
\hline 10 & 89 & 86 & -3 & 0 \\
\hline 11 & 79 & 79 & 0 & 0 \\
\hline 12 & 89 & 89 & 0 & 0 \\
\hline 13 & 83 & 82 & -1 & -1 \\
\hline 14 & 78 & 80.5 & 2.5 & 0.5 \\
\hline 15 & 80.5 & 78.5 & -2 & 0 \\
\hline 16 & 90 & 91 & 1 & 1 \\
\hline 17 & 74 & 70 & -4 & -1 \\
\hline 18 & 80 & 77 & -3 & -1 \\
\hline 19 & 79 & 77 & -2 & 0 \\
\hline 20 & 93 & 90.3 & -2.7 & 0.3 \\
\hline 21 & 76 & 74 & -2 & 0 \\
\hline 22 & 82 & 79.4 & -2.6 & 0.4 \\
\hline 23 & 76 & 71.5 & -4.5 & -0.5 \\
\hline 24 & 82 & 82 & 0 & 0 \\
\hline 25 & 75 & 77 & 2 & 0 \\
\hline 26 & 85 & 81 & -4 & 0 \\
\hline AVG & $\begin{array}{c}83.07 \pm \\
5.82\end{array}$ & $\begin{array}{c}81.39 \pm \\
5.83\end{array}$ & $\begin{array}{c}-1.67 \pm \\
2.10\end{array}$ & $\begin{array}{c}0.05 \pm \\
0.51\end{array}$ \\
\hline
\end{tabular}

PVC: planned vertical change of the maxilla. NP: nasal Pin. Pre: preoperative position. Post: postoperative position. AVG: average \pm standard deviation. 
Table III. Intraoperative measurements using medial canthus reference and its comparison with the vertical position defined in the pre-surgical planning.

\begin{tabular}{|c|c|c|c|c|}
\hline Patient & $\begin{array}{c}\text { EMC Pre } \\
(\mathrm{mm})\end{array}$ & $\begin{array}{c}\text { EMC post } \\
(\mathrm{mm})\end{array}$ & $\begin{array}{c}\text { EMC pre/ } \\
\text { post } \\
\text { difference } \\
(\mathrm{mm})\end{array}$ & $\begin{array}{c}\text { PVC/EMC } \\
\text { post } \\
\text { difference }\end{array}$ \\
\hline 1 & 66 & 64.5 & -1.5 & 2.5 \\
\hline 2 & 65 & 64 & -1 & -1 \\
\hline 3 & 63 & 62 & -1 & 1 \\
\hline 4 & 64 & 60 & -4 & 2 \\
\hline 5 & 56.5 & 56.5 & 0 & 0 \\
\hline 6 & 61.4 & 59 & -2.4 & 0.6 \\
\hline 7 & 63 & 65 & 2 & 2 \\
\hline 8 & 57 & 56 & -1 & 2 \\
\hline 9 & 57 & 55 & -2 & 1 \\
\hline 10 & 65 & 65 & 0 & 3 \\
\hline 11 & 61 & 63 & 2 & 2 \\
\hline 12 & 68 & 68 & 0 & 0 \\
\hline 13 & 63 & 62 & -1 & -1 \\
\hline 14 & 57 & 61 & 4 & 2 \\
\hline 15 & 63 & 62 & -1 & 1 \\
\hline 16 & 65 & 69 & 4 & 4 \\
\hline 17 & 59 & 56 & -3 & 0 \\
\hline 18 & 59 & 59 & 0 & 2 \\
\hline 19 & 65 & 63 & -2 & 0 \\
\hline 20 & 72 & 72 & 0 & 3 \\
\hline 21 & 51 & 50 & -1 & 1 \\
\hline 22 & 64 & 62 & -2 & 1 \\
\hline 23 & 63 & 61 & -2 & 2 \\
\hline 24 & 62 & 63 & 1 & 1 \\
\hline 25 & 53 & 54 & 1 & -1 \\
\hline 26 & 63 & 61 & -2 & 2 \\
\hline AVG & $\begin{array}{c}61.76 \pm \\
4.59\end{array}$ & $\begin{array}{c}61.26 \pm \\
4.84\end{array}$ & $\begin{array}{c}-0.49 \pm \\
1.94\end{array}$ & $\begin{array}{c}1.23 \pm \\
1.29\end{array}$ \\
\hline
\end{tabular}

PVC: planned vertical change of the maxilla. EMC: medial canthus reference. Pre: preoperative position. Post: postoperative position. AVG: Average \pm standard deviation.

\section{DISCUSSION}

To determine sagittal and transverse movements, splints are used ${ }^{4,5}$ and to determine a correct position of the maxilla in the vertical direction a stable reference point is required to adequately control the amount of gingival and central incisor exposure ${ }^{6}$. Generally, this is achieved through the use of ERPs ${ }^{7}$. Nasal pin is the most widely used ERP, moreover, the use of EMC has been promoted as an ERP, arguing that despite being a soft tissue, it is a firmly fixed structure that has no mobility or distortion during the handling of the maxillomandibular complex $(\mathrm{MMC})^{5}$.
The results obtained in our study indicate that there is some degree of distortion in the measurement, evidencing greater accuracy in vertical maxillary repositioning when using an NP compared to EMC as ERP. Obtaining a deviation of $0.05 \pm 0.51 \mathrm{~mm}$ using NP and $1.23 \pm 1.29 \mathrm{~mm}$ using EMC. The differences obtained with the EMC may be due to the fact that being a soft tissue it is susceptible to movement and distortion when manipulating neighboring structures and the use of nasotracheal intubation.

At present, the use of a K-wire located in the nasion as NP is common, since it provides a stable point to measure the vertical dimension from this point to the orthodontic arch at the level of the upper central incisors ${ }^{1}$. The accuracy obtained in our results using NP was an average distortion value of $0.05 \mathrm{~mm}$ with a maximum of $0.56 \mathrm{~mm}$. This is relevant, because an unplanned clockwise or counterclockwise rotation due to the lack of vertical accuracy in the position of incisors and/or molars could generate changes in the inclination of the occlusal plane, with the consecutive increase or decrease in the projection of the chin due to the effect of mandibular self-rotation.

The virtual preoperative planning in the coronal plane with maxillary vertical adjustment is bony and based on the position of fixed bone elements or defined planes, in relation to the maxillary teeth. Regarding this, Lonic et al. analyzed CBCTs using a standardized 3D frame and three horizontal reference planes maxillary cant detection. This study revealed that the Frankfort horizontal (FH) plane was the best method for cant detection in 3D imaging. On the other hand, in conventional surgery the vertical reference is obtained by means of transverse lines made in the articulated models, extrapolated from radiographic reference points. However, these landmarks are used intraoperatively to determine the vertical position of the maxilla and relate it to what was planned preoperatively, inaccuracies with these methods may occur ${ }^{9}$.

Another problem is the effect of triangulation generated by the sagittal or transverse movements of the maxilla are generally not considered. The distance between the ERPs (EMC or NP) and the dental reference (orthodontic arch and / or bracket) is currently represented by the hypotenuse of a right triangle rather than a purely vertical measurement $\mathrm{t}^{10}$. According to Kretschmer, this geometric effect is less than $1 \%$ in the sagittal movements of the maxilla up to 10 millimeters 6 . Not being aware of this phenomenon, in great advances or in combined movements, the maxillary complex will probably be fixed in a more superior position, by the attempt to maintain the programmed measurement ${ }^{6}$. The average maxillary advancement in our study was $4.57 \mathrm{~mm}$, insufficient to generate a relevant distortion.

Some authors have reported the use of vertical positioning guides in conjunction with splint using computer-assisted surgical simulation ${ }^{9-13}$. Others have used simulation systems that allow obviate the use of an intermediate splint $\mathrm{t}^{14}$, they have even developed robotic assisted methods to accurately transfer a preoperative virtual plan into the intraoperative ${ }^{15}$. These methods could be the future of repositioning the MMC in the three planes of space with minimal chance of error, however, the associated costs are high.

Assisted OS with cut guides and custom surgical plates for Le fort I, which predetermine vertical positioning, could make 
intraoperative vertical measurement less relevant. However, in some cases this involves complex, high-cost preoperative planning and the blockage in the vertical position of the maxilla predetermined by these elements would not allow an intraoperative aesthetic judgment to alter or manipulate incisal exposure ${ }^{9}$. This is why, despite the fact that measurements with ERP reference points are widely used, for its easy clinical application, practicality and its possibility of modification by the clinical judgment of the surgeon, they are a fundamental tool in the intraoperative management of the maxilla.

Despite the fact that each technique has its limitations, defining which of the two ERPs is more accurate for linear movements has great utility in the intraoperative period, being aware of the triangulation effect suffered by oblique measurements (Figure 3). To decrease these effects, it is recommended to use a linear measurement as perpendicular as possible from the selected reference point, for example, for positioning of the incisors and dental exposure, it is recommended to use a nasal pin with either a K-wire in the nasion or glabellar region, the 40 millimeter length of the pin ensures that it can accompany the advancement of the maxilla in sagittal movements to avoid angulation from the nasion to the dental landmark. For handling of maxillary plane cant at the canine level, we recommend the use of the EMC, which despite having a higher degree of imprecision than the pin, the measurement would be linear, minimizing possible intraoperative positioning errors, both being complementary ERPs according to the requirements of the sagittal and vertical movement of our patient.

The NP it is easy to handle and reports of are scarce and no intraoperative or postoperative complications associated with this technique were observed in this study. For what is considered a safe technique, in addition to the use of the medial canthus in maxillary positioning, it will be possible to have the best vertical control in the mid and lateral sectors of the maxilla.
This corroborates that the use of both ERPs is a valid precedent for repositioning of the maxilla, the use of NP being more precise for movements in the incisor sector. Intraoperative measurements are a guide and their correct measurement is important to ensure that a cant is corrected or has not been created.

The limitations of our study are related to the measurement error inherent to the operator-dependent measurement and sensibility, also to the selection of the dental reference point. To decrease this error, only one operator performed all intraoperative measurements and repositioned the maxilla in all cases.

Future studies to standardize techniques with repositioning assisted by intraoperative simulation and even robot-assisted surgery can be supported by the results obtained in this study that evaluates the currently most used techniques as a point of start.

\section{CONCLUSION}

Proper vertical positioning of Le Fort I is important to achieve the desired aesthetic result in OS. Our results demonstrate predictable results between intraoperative vertical bone measurements. The use of the NP as an ERP provides greater precision and predictability of movement in the vertical repositioning of the maxilla in OS, compared to the use of the reference of the EMC. Both techniques can be used as a complement, being aware of the effect of triangulation affected by the advancement and the requirements of vertical repositioning of the maxilla. Understanding this relationship allows the clinician to be guided in choosing intraoperative measures to reproducibly determine the desired vertical position of the bone, using simple methods for clinical practice.
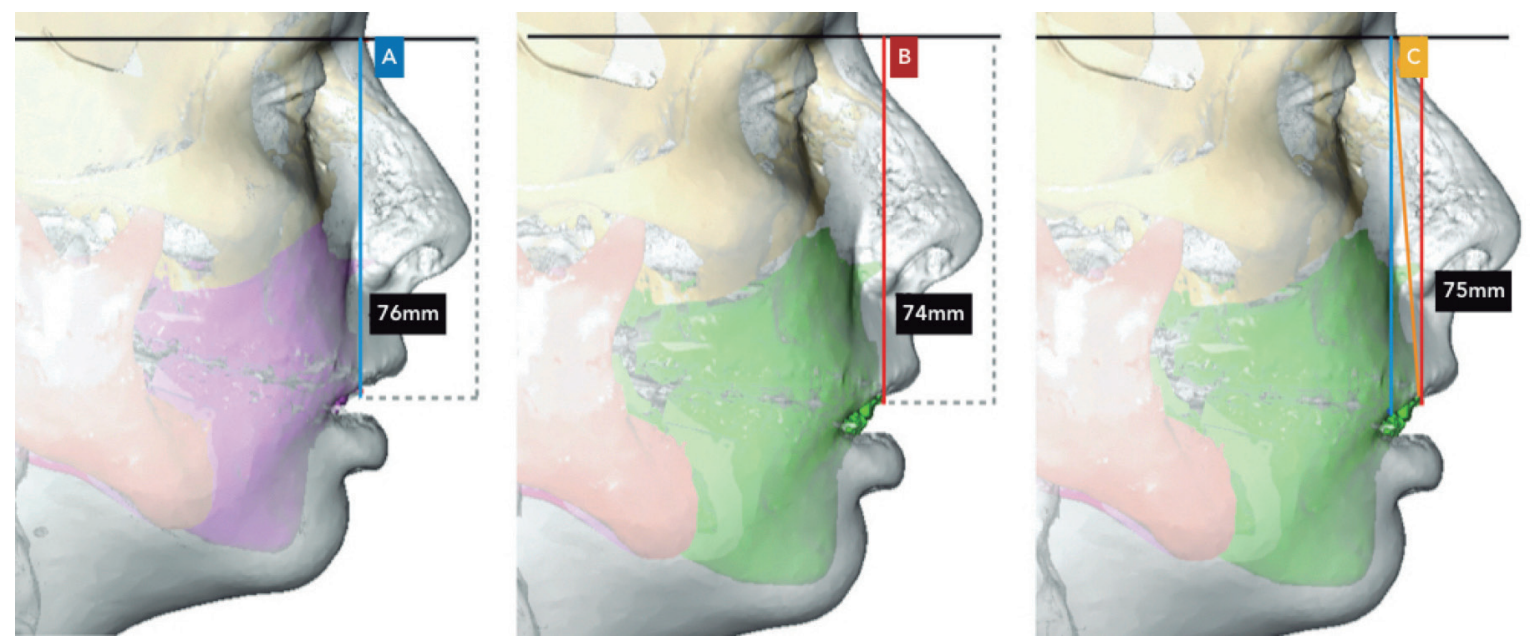

Figure 3. Three-dimensional reconstruction of a СBCT scanner of patient 21 in maxillary advancement planning. Differences in distance from incisor dental reference to horizontal plane (HP) at NP level at different angulations. A) Presurgical distance from HP to dental reference at 90 degrees. B) Post-surgical planned distance from HP to a dental reference at 90 degrees.

C) Post-surgical distance angled from HP to dental reference. 


\section{Acknowledgments and disclosure statements}

The authors report no conflicts of interest related to this study.

\section{R E F E R E N C E S}

1. Solé P, Reininger D. Análisis de la ubicación vertical y profundización del pin frontal en cirugía ortognática. Rev Esp Cir Oral Maxilofac. 2012;34(2):47-50. DOI: 10.1016/j.maxilo.2012.01.002.

2. Kim SG, Park SS. Incidence of complications and problems related to orthognathic surgery. J Oral Maxillofac Surg. 2007;65(12):2438-44. DOI: 10.1016/j.joms.2007.05.030.

3. Chow LK, Singh B, Chiu WK, Samman N. Prevalence of postoperative complications after orthognathic surgery: a 15-year review. J Oral Maxillofac Surg. 2007;65(5):984-92. DOI: 10.1016/j. joms.2006.07.006.

4. Gil JN, Campos FE, Claus JD, Gil LF, Marin C, de Freitas SF. Medial canthal region as an external reference point in orthognathic surgery. J Oral Maxillofac Surg. 2011;69(2):352-55. DOI: 10.1016/j.joms.2010.07.023.

5. Kretschmer WB, Zoder W, Baciut G, Bacuit M, Wangerin K. Accuracy of maxillary positioning in bimaxillary surgery. Br J Oral Maxillofac Surg. 2009;47(6):446-9. DOI: 10.1016/j.bjoms. 2009.06.004.

6. Iwai T, Omura S, Honda K, Yamashita Y, Shibutani N, Fujita K, et al. An accurate bimaxillary repositioning technique using straight locking miniplates for the mandible-first approach in bimaxillary orthognathic surgery. Odontology. 2017;105(1):1226. DOI: 10.1007/s10266-016-0236-7.
7. Ruckman P 3rd, Schlieve T, Borba AM, Miloro M. External Reference Nasal Pin for Orthognathic Maxillary Positioning: What Is the Proper Method of Placement? J Oral Maxillofac Surg. 2016;74(2):399.e1-9. DOI: 10.1016/j.joms.2015.10.004.

8. Lonic D, Sundoro A, Lin HH, Lin PJ, Lo LJ. Selection of a horizontal reference plane in 3D evaluation: Identifying facial asymmetry and occlusal cant in orthognathic surgery planning. Sci Rep. 2017;7(1):2157. DOI: 10.1038/s41598-017-02250-w.

9. Tsay CJ, Sawh-Martinez R, Bruckman K, Veeramani A, Steinbacher D. Do Vertical Soft Tissue and Actual Bony Landmarks Correlate in Le Fort I Orthognathic Surgery? J Oral Maxillofac Surg. 2019;77(4):828-33. DOI: 10.1016/j.joms.2018.11.018.

10. Espinosa SS. Vertical Maxillary Measurements using a Virtual External Reference Point in Orthognathic Surgery: Technical Innovation. J Craniofac Surg. 2017;28(8):2101-3. DOI: 10.1097/ SCS.0000000000004170.

11. Bouchard C, Landry PÉ. Precision of maxillary repositioning during orthognathic surgery: a prospective study. Int J Oral Maxillofac Surg. 2013;42(5):592-6. DOI: 10.1016/j.ijom.2012. 10.034 .

12. Ahn J, Mah J, Kim J, Park Y. Orthognathic surgical planning using nasion true vertical and true horizontal lines. J Clin Orthod. 2012;46(7):407-15.

13. Füglein A, Riediger D. Exact three-dimensional skull-related repositioning of the maxilla during orthognathic surgery. $\mathrm{Br}$ J Oral Maxillofac Surg. 2012;50(7):614-6. DOI: 10.1016/j. bjoms.2011.11.001.

14. Lee SJ, Woo SY, Huh KH, Lee SS, Heo MS, SC, et al. Virtual skeletal complex model- and landmark-guided orthognathic surgery system. J Craniomaxillofac Surg. 2016;44(5):557-68. DOI: 10.1016/j.jcms.2016.02.009.

15. Woo SY, Lee SJ, Yoo JY, Han JJ, Hwang SJ, Huh KH, et al. Autonomous bone reposition around anatomical landmark for robot-assisted orthognathic surgery. J Craniomaxillofac Surg. 2017;45(12):1980-8. DOI: 10.1016/j.jcms.2017.09.001. 